

\section{Abstract}

This article is concerned with the training and curing practices of Betsileo ombiasa ('healers-diviners'), and their relationships with biomedical practitioners and Christian healers, in particular Fifohazana exorcists. We first give an account of what we think is characteristic in the process of becoming an ombiasa, highlighting in particular the role of ancestors and other spiritual entities. We then give a brief description of the ombiasa's healing practices and the kind of remuneration they usually ask for. In the last part of the article we discuss their collaboration and conflicts with other health practitioners, showing how ombiasa are constantly adapting their practice to avoid open confrontations with their competitors, accommodate their patients' expectations and continue to carve out a niche for themselves within Betsileo medical pluralism.

Keywords: anthropology, Betsileo, religion, healing, medical pluralism, Madagascar 


\title{
The Place of Healers-Diviners (Ombiasa) in Betsileo Medical Pluralism
}

\author{
O. Legrip-Randriambelo \& D. Regnier
}

\section{Introduction}

Faneva is a young Betsileo girl who has experienced physical and psychological problems since her birth. ${ }^{1}$ Over a long period her family brought her to several healers-diviners (ombiasa), but their repeated attempts at curing the girl did not succeed. Faneva's mother, who was working as a gardener in a Catholic religious institute, asked a priest to find a solution. The priest first tried to improve the girl's health through Catholic prayers but this treatment did not have the effect he expected. After a discussion between the girl's family, the priest and Sisters in the congregation, it was decided to drive Faneva to Protestant healers in a Fifohazana toby ('camp', i.e. a Fifohazana center) where she would be taken care of and exorcised. She left the toby healthy - at least according to the Protestant exorcist - but at home she fell ill again and was immediately sent back to the toby. After a week, however, the priest and the Sisters took her out of the toby and brought her to a Catholic dispensary. There, a lay biomedical practitioner prescribed Faneva some fanafody vazaha ('foreign medicines', i.e. chemical medicine). Sadly, this treatment also failed to cure her.

The story of Faneva illustrates the fact that the Betsileo, who live in the southern highlands of Madagascar, have easy recourse to different kinds of health practitioners when they are faced with illness. ${ }^{2}$ In this article we focus on the activities of healers-diviners, called ombiasa or omasiñ (a contraction of olo masina, 'sacred man'), and the place they occupy in the context of health care in Betsileo country. We give an account of what we think is characteristic in the process of becoming an ombiasa and in working as such, in an environment where healersdiviners have to compete with biomedical practitioners on the one hand and various kinds of Christian healers on the other. Our account relies on the extensive ethnographic fieldwork that we have conducted in southern Betsileo country, in the 'rurban' context of Fianarantsoa and its vicinity (Olivia Legrip-Randriambelo) as well as in the more rural setting of Beparasy, in the south of the Matsiatra Ambony region (Denis Regnier). Although we interviewed a large number of ombiasa, attended a range of curing sessions and talked to numerous patients, we do not claim to have studied the subject exhaustively, since there is great variation in how people become ombiasa and in how they practice their art. Rather, our aim here is to capture some of the most characteristic features of the ombiasa's activities in present-day Betsileo country.

The Betsileo were among the earliest groups in Madagascar to be Christianized and, partly because of this, they are rather well schooled compared with other societies on the island (Freeman 2001). Therefore, they are often viewed as one of the most 'westernized' groups in Madagascar. At the same time, however, ethnographers of the Betsileo have often noted their conservatism (Kottak, 1980) and the "tenacity of tradition" (Kus and Raharijaona

\footnotetext{
${ }^{1}$ Personal names have been changed to preserve anonymity.

${ }^{2}$ For extensive accounts on the Betsileo see in particular Dubois (1938) and Kottak (1980).
} 
2000) among them. These somewhat contradictory aspects of their ethos are well illustrated by their therapeutic itineraries which, as we have seen in the case of Faneva, are characterized by back-and-forth movements between different healing practices - some being considered 'western' (vazaha) and 'modern' (évolué) and others viewed as 'ancestral customs' (fomban-drazana). As we will show, these itineraries potentially lead to oppositions and conflicts that, if they do not always need to be resolved, must always be dealt with in one way or another. This is particularly true of Betsileo ombiasa, who as traditional practitioners constantly need to adapt their activities in order to re-negotiate their place and legitimacy within the 'health system' writ large. As we will show, a focus on ombiasa and their practices is crucial to understanding the landscape of Betsileo medical pluralism.

In the first part of the article we explain how people become ombiasa. We show that the healers' individual trajectories and their communication with the ancestors are important to understanding the ombiasa's function: this is both as a vocation, in the sense that at some point in their life they strongly felt their suitability for this particular occupation, and a duty, in the sense that they also had the intuition that they had been 'chosen' to carry on someone else's practices, often those of an ancestor. The following part of the article is concerned with the basics of the ombiasa's trade and will provide a short description of their various practices, the material they use, the medicine they prescribe and the way they are compensated for their services. In the last part we address the issue of their collaboration and conflicts with the biomedical practitioners who work in dispensaries, health centers and hospitals on one side and with Christian exorcists on the other side, in particular those who belong to the indigenous revival movement called Fifohazana.

\section{Becoming Ombiasa}

Being an ombiasa is usually not an occupation that someone has chosen and learnt in a structured manner, for example by following the teaching of another ombiasa. ${ }^{3}$ Among the Betsileo, one most commonly becomes ombiasa through the conjunction of two factors: an experience of severe illness and recovery from it, and a form of transmission of a 'healing gift' often due to the presence of an ombiasa among one's ancestors or kinsmen. More rarely, the process of becoming ombiasa also involves going through specific rituals. In some occasions the knowledge and techniques are learnt through explicit teaching.

According to our ethnographic data, many Betsileo ombiasa become aware of their gift after an episode of severe illness - typically a strong fever, a paralysis or a temporary blindness - from which they recover. This is the case, for example, of Berthine and Thérèse, two female ombiasa from Fianarantsoa. Berthine, who suddenly became paralyzed and lost her ability to speak, had to slowly re-learn to walk and speak, whereas Thérèse, who suffered from temporary blindness, had progressively to rediscover the visual world. Both of them spoke of their recovery as a kind of 'rebirth', using the French word renaissance. Illness here seems to play the role of a catalyzer, since it is through recovery from an episode of severe affliction that ombiasa become fully aware of their gift and strongly feel that it is their vocation to cure people.

Such a revelation about a specific healing gift is often facilitated by the presence, within the family, of other healing figures. Frequently ombiasa have 'taken the hand' (mandray tanàna) of another healer among their kinsmen at the time of the healer's death, and they report a transmission of this healer's gift to them. When they treat their patients, ombiasa work 'with' their ancestors, and these have often been ombiasa too, although it is not necessarily the case. Moreover ombiasa can also work with other kinds of spirits, for example royal spirits or natural

\footnotetext{
${ }^{3}$ For a more general study of healers-diviners in Madagascar, see Delphine Burguet's recent PhD thesis (2014).
} 
spirits such as kalanoro. ${ }^{4}$ When explaining how they have become ombiasa our informants often mentioned a kind of duty, stressing that they did not have a choice but were chosen to accomplish their functions. For example Pierre, a young ombiasa from Beparasy, explained that after his father's death the fanafody ('remedies', i.e. here the collection of materials used by ombiasa) had been moved to his sister's house: she then started treating people with them, whereas Pierre and his other siblings were not keen on taking up their father's practice. After some time, however, the sister had to recognize that it was not working for her - she could not use the fanafody. The fanafody were moved to several other houses in the kin group's hamlet until finally they were placed in Pierre's house and there were signs that he was the one who could use them most successfully. Pierre explained that the fanafody had chosen him and thus he had felt obliged to continue his father's activities. He accepted this duty somewhat reluctantly.

If in most cases there is no structured teaching on how to become an ombiasa, people like Pierre have already learnt a lot since their childhood from observation of their ombiasa kinsmen - Pierre's father in this case. As shown by Astuti's research on Vezo children's beliefs about ancestors and the afterlife, children's learning can be very effective even when adults do not teach them anything, on the grounds that they are too young to understand the issues at stake (Astuti 2012). Long before taking up their office, potential ombiasa have most likely acquired a good knowledge of plants, especially the varieties of wood, and of the ritual interventions that ombiasa use to heal the sick. Being brought up in a family where ombiasa already operate thus significantly increases the likelihood that one will become ombiasa oneself.

Two examples from Beparasy will illustrate and complicate the points we have just made. The first case is that of Rasoa, whose father was an ombiasa. Rasoa explained that she received her father's gift but did not want to practice the ombiasa's art of healing because she is Christian (more precisely Lutheran (FLM) - we will come back to issues of incompatibility later on). Yet she acknowledged at the same time that she could not entirely put her gift aside and live as if it did not exist. For example, she said that she felt intense emotions when something went wrong in a house or in an assembly (when for example some witchcraft had been done) and in such cases she felt forced to 'do things' (manao zavatra) with traditional remedies (fanafody) and rituals to protect, cleanse or cure her closest relatives, in particular her children. Rasoa, therefore, is convinced that she has received her father's gift but she remains reluctant to accept the duty of carrying on his practice because of her Christian faith.

Rakoto's case is quite the opposite. Unlike Rasoa, Rakoto did not have a close parent or ancestor working as an ombiasa. In his teens, however, he became interested in the activities of ombiasa and wanted to become one. Since he knew that a locally reputed practitioner, an ombiasa tsy maito, ${ }^{5}$ lived close to his village he went to talk to him and asked if he could become his apprentice. The old ombiasa agreed and taught Rakoto his art. During his

${ }^{4}$ Kalanoro are small, red-eyed human-like sylvan spirits, with long hair from which they take their strength. Holders of magico-religious powers and experts in the Malagasy pharmacopoeia, they nonetheless have a bad reputation since they are associated with alcoholism, robbery and violence.

${ }^{5}$ In Beparasy, people make a distinction between three types of healers-diviners: ombiasa maribola, ombiasa tsy maito and ombiasa andolo. The maribola type is identified as a tradition coming from the Bara (the southern neighbours of the Betsileo) whereas the tsy maito is said to come from the Taimoro, a group reputed for its magico-religious knowledge on the eastern coast of Madagascar. According to Rakoto, it is not rare that southern Betsileo ombiasa travel to the Bara or Taimoro regions to learn how to improve their art. Ombiasa andolo are not identified with a local tradition but their name stresses that they are people who can speak to the 'spirits' (lolo). It is interesting to note that in Beparasy the expression ombiasa tanala (the Tanala are the eastern neighbours of the Betsileo) refers to sorcerers. 
apprenticeship Rakoto had to go through a number of initiation rituals, after which he started practicing. He did so during most of his adult life, until he converted to Catholicism in his sixties and read in the Bible that, as he put it, “divination was not a good thing”. Although we did not come across many cases like this, Rakoto's story shows that it is possible to 'start afresh' and learn to become an ombiasa without necessarily having ombiasa kinsmen or ancestors.

An interesting example of how one becomes ombiasa is that of Raveloñandro from Fianarantsoa, whose story encapsulates some features that we have described, namely the episode of illness, the transmission of a gift, the importance of ancestors and the passage through a liminal stage and initiation rituals. Raveloñandro explained how one day he and his father both became very sick. As he was recovering and becoming slowly aware of his gift, Raveloñandro organized a ritual called rombo, during which he danced and sang for three days, inviting his ancestors to come to him. After this ritual had been performed, his father could eventually die and Raveloñandro was drawn to a sacred river nearby, in which he spent a few hours with zazavavindrano ('princesses of water', i.e. human-like, female aquatic creatures). After this second initiatory stage he became fully aware of his gift and able to practice as an ombiasa. He explained: "Ancestors (razana) chose me to do that and these are my ancestors. One of them is Randriatsiaherina, and he is my grandfather. When he died, I got the knowledge of these things. It was passed on to me" (Ireo razana no nifidy ahy hanao an'izao. Ary, ireo razan'ireo, dia razambeko. Ny anarany dia Randriatsiaherina, dadabeko io. Ary refa nody mandry izy, dia nanomboka nahalala io zavatra io aho; ary tonga tamiko izany). ${ }^{6}$

From what we have heard, it seems that a majority of Betsileo ombiasa inherit the gift of healing, the divinatory skills and the material for concocting remedies (fanafody) from a kinsman, and most often from a forebear. Yet our ethnography also shows that this kind of transmission is not at all easy. It is a difficult process, during which the person is put to the test. The possibility of refusing the ancestral call and its final acceptance after episodes of acute suffering appears to be central elements in the process. Socially, such a personal history of becoming-through-suffering gives healers-diviners their credentials and enhances their prestige. Subjectively, the process renders ombiasa progressively more conscious of their gift and increasingly confident in their use of the fanafody.

\section{Basics of the Ombiasa's Trade}

An ombiasa's healing session usually starts with divination. The apparatus used may vary but it often consists of mirrors, seeds and/or playing cards with signs written by the healer-diviner. In his divinatory practice the ombiasa follows the lunar calendar (an example of Arabic influences on Malagasy culture) and asks for his patient's birth date to determine their vintana (destiny). After this initial divinatory moment the ombiasa proceeds to the healing. Depending on his specific gift and the techniques he has learnt, he administers massages, anointing, inhalation or fumigation. He also prepares remedies made of elements that can be vegetal (e.g. plants, grated wood), mineral (e.g. kaolin) or animal (e.g. chicken claws, starfish), and often he uses shells, glass or plastic beads, silver bracelets or coins. The preparation of remedies is an integral part of the healing session since the ombiasa concocts them in front of his patients after having communicated with his ancestors and often he continues to speak to both patients and ancestors while making the preparation.

\footnotetext{
${ }^{6}$ In addition to his grandfather, Raveloñandro works with four other ancestors.
} 
The way Raveloñandro enters into communication with his ancestors can serve as an illustration of how ancestors assist the ombiasa in performing his job. During the consultation Raveloñandro calls on the ancestors via a mirror bearing six marks made with kaolin paste (tany ravo or tany fotsy) mixed with water fetched from a sacred river. Like most Betsileo ombiasa, he uses a mirror both for divination and for communication with the ancestors. ${ }^{7}$ The ancestor who is most qualified to treat his patient provides him with advice and appropriate remedies. Raveloñandro says he cannot see this ancestor in the mirror, but he can hear him. What he can see in the mirror, he claims, are the persons who have bewitched his patients or those who do them good.

It is important to note here that besides the consultation and treatment of the ombiasa a number of offerings are made by the patient's family to their ancestors to ask for their help in the healing process. Typically, artisanal rum (toaka gasy), honey and candles are placed on the domestic altar located in the zoro-firarazana (the 'ancestors' corner', in the southeastern corner of the Betsileo house), on the family tomb or on the tombs of powerful vazimba. ${ }^{8}$ This point is worth making since it shows that in traditional medicine the ancestors of both the ombiasa and the patient are assumed to work together, in a complementary way, towards the patient's recovery.

In most cases, ombiasa do not ask for specific compensation for their services, but when remuneration is offered it needs to follow certain rules, often an obligation or taboo ( $f a d y)$ related to the practice of an ancestor. For example, a sum of money will have to include the figures 6 or 7. Remuneration can also be paid in kind, in which case it usually consists of rice or rum. Some ombiasa do not ask for payment for the consultations but require the meat of the animal that will have to be slaughtered (i.e. a chicken for minor diseases and an ox for more serious, long-lasting illness) to thank the ancestors if the treatment is successful and the patient is cured. This a very important aspect of the ombiasa's practice, since it is perceived as a more cost-efficient way of healing compared with biomedical treatments. The latter are expensive even when they fail, whereas ombiasa receive payment only if their patients recover.

\section{Relationships and Incompatibilities with Christian Healing Practices}

Non-Christian ombiasa ignore more than denigrate Christian healing practices. Their line of reasoning seems to be that they treat the sick with ancestral remedies and the help of ancestors, while Christians have recourse to God's might to heal their patients. ${ }^{9}$ Christian churches however do not necessarily share such a 'tolerant' division of labor. The case of the Fifohazana is particularly eloquent on this matter. Rainisoalambo, a former ombiasa, converted to Christianity and in 1894 founded this Protestant movement in the Betsileo village of Soatanàna. Fifohazana means 'awakening' and the movement indeed has some of the characteristics of awakening churches,

${ }^{7}$ Mirrors also play an important role in the auscultation of painful zones in the body. With their mirrors ombiasa scrutinize the possible presence of sisika ('things that have been inserted'), which are small wood pieces from a coffin or a funerary stretcher. Sorcerers (mpamosavy) place them in the way of the persons they target, so that they enter their body. Ombiasa proceed to their extraction by sucking them through the patient's skin and spitting them out.

8 Throughout Madagascar, vazimba is a generic name that allegedly refers to the first inhabitants of the island. Ancient megaliths, caves or tombs are often associated with the vazimba.

9 Besides non-Christian ombiasa, there are a limited number of ombiasa who identify as either Catholic or Protestant. They have syncretic healing practices that associate Christian with ancestral figures. 
yet it remains an integral part of the Malagasy Lutheran church (FLM - Fiangonana Loterana Malagasy). Because of its Betsileo origins, the movement is well represented in Betsileo villages, even the most rural ones, where its most active members are lay exorcists called mpiandry ('shepherds').

In contrast to the ombiasa's attitude towards Christian healing practices, the mpiandry never miss an occasion to virulently condemn the ombiasa's work and influence in their preaching and healing sessions. Moreover, when sick persons arrive in a Fifohazana toby they are systematically interrogated and searched by the mpiandry, who want to know the details of their therapeutic itinerary. The mpiandry are well aware that in most cases this itinerary has begun with the consultation of an ombiasa. Their goal is to get rid of the fanafody that might have been prescribed by ombiasa and that the patients might have brought with them to the toby. When found, these fanafody are ostentatiously burnt in a fire while people sing Christian hymns.

From the point of view of the sick, however, primacy is almost always given to ombiasa and more specifically to the family's own ombiasa (often called mpitaiza, 'carer') or the one who lives in the ancestral village. One of our informants explained that in spite of being a committed Christian she has no doubt that "if something happens in the family one needs to go to the mpisikidy ['diviner'] and the ombiasa". Indeed, we observed on one occasion that following a health problem that seemed to have its roots in sorcery she chose to consult an ombiasa rather than seek the support of Christian healers. As we have seen with the case of Faneva at the beginning of the article, it is generally when ombiasa are not successful that the sick choose to turn to Christian healers. It is not unusual to see people simultaneously consulting ombiasa and Christian healers.

On the whole we found more compatibility than we expected between the work of the ombiasa and the views of the most important Christian churches in Betsileo country, especially when people make the explicit distinction between appealing to the power of the ancestors and appealing to the power of the Christian God. In this context of relative tolerance, the case of the Fifohazana movement and its strong charge against ombiasa requires further explanation. The open enmity of the Fifohazana movement towards the ombiasa's practice and ancestral customs is rooted in the history of its foundation: the movement's founder Rainisoalambo had to violently reject his former activity as an ombiasa before being able to embrace his new Christian vocation. Yet as Lucie JacquierDubourdieu notes, among the Fifohazana "le monde ancestral, pour 'diabolisé' qu'il soit, reste présent et gouverne les conduites" (1996: 608; see also Holder Rich 2008). The Fifohazana movement is indeed characterized by its deep anchoring in Betsileo culture, for example by the use of Zafindraony songs (see Noiret 1995), by the healing techniques of the mpiandry that bear a strong similarity to those of Betsileo ombiasa, and by beliefs in the existence of spiritual entities that are also shared by the ombiasa. Unlike other 'new' Protestant churches that are booming in Madagascar (see Keller 2005 for an example), the Fifohazana movement does not altogether reject the most important aspects of Betsileo culture, and this leaves open the possibility of 'combining', more or less overtly, an engagement in the movement with recourse to the ombiasa's healing practices.

Although these cases are probably not very frequent, we observed a few cases where mpiandry went to consult ombiasa. One of us (Olivia Legrip-Randriambelo) has even encountered the case of a married couple where the husband, RaGilles, works as an ombiasa and the wife, Ralesy, is a mpiandry. The marriage of RaGilles with a mpiandry was considered as strikingly odd (by his patients and by the parish members) because he was not only recognized as a healer but also had the reputation of being a sorcerer. After his marriage, RaGilles took up the role of catechist in his wife's parish. He had to readjust his ombiasa practice to his new Christian environment, and he did so by offering syncretic healing sessions. Yet he did not stop practicing sorcery. Somewhat ironically, the room where he receives his clients is alternately used for holding meetings with Protestant exorcists and for practicing sorcery.

Interestingly, the 'awakening' movement Fifohazana officially fights the healing practices of the ombiasa but accepts close collaboration with biomedical practitioners. Such collaboration can even lead to an alliance of 
convenience between Christian healers and medical doctors against the ombiasa's influence, as the following case will show. It concerns a doctor who works in a small Lutheran dispensary in Fianarantsoa and visits the two toby of the city once a month. As a consequence of his regular visits, all the patients of the toby are also registered and treated at the dispensary. The doctor's prescriptions combine biochemical drugs with Christian prayers and exorcisms but strictly exclude ombiasa remedies. To some patients the doctor does not prescribe any drug at all. In the doctor's terms, their pathology is not something that can be treated with drugs. It can be dealt with only by exorcisms performed by mpiandry since, he says, these patients are possessed by 'devils' (devoly). Like Christian exorcists, the doctor warns his patients that if they return to see the ombiasa the devils will come back, more numerous and mightier than before.

\section{Interactions and Conflicts with Biomedical Practitioners}

In Madagascar the relationships between traditional healing and biomedicine have evolved over more than 150 years. Since at least the second half of the $19^{\text {th }}$ century, ombiasa have been confronted with the rise of biomedicine, first in urban centers and then in rural areas where Christian missionaries opened dispensaries. The first medical school opened in 1864 in Antananarivo (Rakotomalala 2002: 2). Although a number of healers-diviners refused 'foreign medicine' (fanafody vazaha) altogether, many of them did not see serious problems in the addition of vitamins or injections to the repertoire of 'Malagasy medicine' (fanafody gasy), provided these were only used to treat what began to be called 'foreign sickness' (aretina vazaha), that is, 'natural' diseases in opposition to 'Malagasy sickness' (aretina gasy) originating in sorcery (see Legrip-Randriambelo 2014 for an example). According to Janet Harper, the introduction of pharmaceutical medicine among the Tanala has significantly changed the role of local ombiasa, "who appears to have shifted from diviner and healer to primarily diviner" (2002:13) and therefore diminished their contribution to healing. Harper observed that even when the availability of pharmaceutical medicines was curtailed because of impoverishment the role of ombiasa and the use of plant remedies did not necessarily increase.

Among the Betsileo - who are close neighbours of the Tanala - it seems that both cultural and economic considerations have played a role in the enduring success of ombiasa's healing activities and their persistence in spite of the development of biomedical infrastructures. For many peasants in the countryside, long-term access to pharmaceutical medicines, not to speak of stays at the hospital in Fianarantsoa, remains very expensive. If a network of kinsmen cannot provide financial support it is often impossible for them to meet such costs, as recent research has shown in the case of the Toamasina hospital in eastern Madagascar (Mestre 2013: 47-53).

Ombiasa and biomedical practitioners have conflicting views on a number of issues, for example on the respective merits of offerings to ancestors, hospitalization or pharmaceutical medication. Yet sometimes ombiasa try to integrate biomedical procedures into their practice. They commonly use a carnet de santé similar to the small notebook in which consultations and prescriptions by biomedical practitioners have to be recorded, and forms on which they write down their prescriptions (taratasy liste) and posology principles, asking for example that the patients take their remedies three times a day before meals.

In Antananarivo, a national association of tradithérapeutes (ANTM: Association nationale des tradipraticiens malgaches) was created in 1997 in agreement with the Ministry of Health and the OMS/Madagascar (Corrèges, 2014: 181). This marked a clear shift in the relationships between the Malagasy state and healersdiviners, since the latter have long been held in suspicion by the former. The association contacts ombiasa and invites them to register at the nearest health center to get a carte d'adhérent (membership card). In return, ombiasa are expected to give a monthly report about the patients they have treated (giving their name, age, sex, as well as 
their pathologies and the remedies prescribed). The national association has few members in the Betsileo region, and all of these practice in urban contexts, mainly in Fianarantsoa. Most of them, however, do not send the reports to health centers. Among the twenty or so ombiasa registered at the centre de santé de base II at Manaotsara in Fianarantsoa, for example, we found that only one was sending his reports. The monthly reports are sent by the center to the district health administration, which forwards them to the Ministry of Health in Antananarivo.

Although the association is not very successful among Betsileo ombiasa, we observed that patients do sometimes check the affiliation of the ombiasa they are consulting. The following excerpt from an interview with Raveloñandro illustrates not only his perception of the role of medical doctors, but also a reluctant ombiasa's view of the association and of his patients' demands on this matter:

There are people who are being cured [...] they should give some money [...] they can borrow it. They say they will pay afterwards, for example $25000 \mathrm{Fmg}$. When they are feeling better, after one month, two months, I see these people and I ask them for the money. They ask: "Where is your paper?" [i.e. the association membership card] ! And then they call the police because I have no paper. That's how things are here. The police bring me to their office, but I have done nothing so I don't go to jail. Then I go out, they set me free like that. We are doctors, there are things that the doctors [i.e. the medical doctors] say they don't know but we know.

As Leslie Sharp, who worked on spirit possession in Ambanja (north-west Madagascar), suggests: "medical pluralism is an essential element of life in Madagascar, where a wide variety of healers and healing practices operate. [...] The domains of indigenous practices and Western biomedicine cannot be described as distinct or [...] complementary. Rather, the boundaries between these healing systems fluctuate depending heavily on the skills of the healer, the preferences of the client, and on economic constraints" (1993: 203). The fluctuation of boundaries was obvious in a number of cases we observed, in which medical doctors sent their patients to ombiasa - for example because sorcery was suspected or because a birth was expected to be problematic, in a rural context where basic obstetric equipment was lacking - and ombiasa preferred to re-direct the patients they felt they could not cure to the dispensary rather than to rival healers. Both sides rarely acknowledged such cases of collaboration, yet they were in no way exceptional. Whenever a patient needs different kinds of healthcare the general attitude seems to be that ombiasa and medical doctors "do not seek to discredit each other's methods or knowledge, but view them at times as complementary, at others as distinct or as providing different solutions to the same sorts of problems" (Sharp 1993: 207).

This does not mean however that doctors and ombiasa do not have a strong prejudice against each other. A good number of practitioners on both sides claim that they never cooperate with their counterparts. Ombiasa in Fianarantsoa frequently told us that they have to "remedy the errors" of surgeons, and many doctors do not miss an occasion to stress that ombiasa are incompetent because they have not been academically trained. Many of the ombiasa we met were proud to say that they never had to see a doctor.

\section{Conclusion}

In spite of enduring prejudice and occasional conflicts, our account shows that, on the whole, healers in the religious-therapeutic field seek to juxtapose and combine practices more than they compete with each other. The typical circulation of actors (both patients and healers) within this field, which can be described in terms of broad patterns, defines what we call "Betsileo medical pluralism". In such a context, it is striking that therapeutic itineraries are not much constrained by religious obedience, even though questions of faith definitely play a role, for example in the choice of the first healing option. 
By way of conclusion, we would like to suggest that the preference for ombiasa in such a pluralistic and open therapeutic landscape should be understood in three ways. Firstly, as we have explained, economic factors play a crucial role since it is usually inexpensive to consult ombiasa and buy the fanafody they need: ombiasa require a major payment only if their patients recover. By contrast, biomedical treatments and consultations are perceived as very expensive even when they do not work. This is particularly true for the Betsileo who live in the countryside, who need to add the cost of traveling to town when they seek biomedical treatment. For these people, in consequence, the ombiasa still play the role of local and accessible general practitioners. Secondly, even when the ombiasa were not their first choice, people often turn to their art of healing when all the other options, including Christian healing, have failed. Without doubt, ombiasa are commonly viewed as the "last resort" within Betsileo medical pluralism, even for practicing Christians. Thirdly, in many cases the choice of ombiasa demonstrates a preference for local, Betsileo healing practices, as opposed to the universalism of Protestant churches or biomedicine. Yet ombiasa are not the only players who occupy this niche: as we have seen, Fifohazana healers and exorcists (mpiandry) also rely heavily on their Betsileo identity. Unsurprisingly, both ombiasa and mpiandry tend to think that their healing practices cannot be combined. As a matter of fact, the various therapists' discourses on the complex religious-therapeutic field often stress that some reconfigurations or therapeutic itineraries are impossible because of alleged incompatibilities. In practice, however, most reconfigurations of the field appear to be operative and most itineraries seem coherent from the patients' point of view.

\section{References}

Astuti, R. 2011. "Death, Ancestors and the Living Dead: Learning Without Teaching in Madagascar". In, Children's Understanding of Death: From Biological to Supernatural Conceptions, edited by V. Talwar, P. L. Harris \& M. Schleifer, 1-18. New York: Cambridge University Press.

Bougerol, C. 1993. "Le cumul magico-religieux à la Guadeloupe." Journal de la Société des Américanistes 79: 91103.

Burguet, D. 2014. "Les devins-guérisseurs dans l'histoire et aujourd'hui. Savoir, action et pouvoir à Madagascar." $\mathrm{PhD}$ diss., École des Hautes Études en Sciences Sociales.

Corrèges, D. 2014. "Intégrer la médecine traditionnelle à Madagascar. Institutions, acteurs et plantes au prisme de la mondialisation. " PhD diss., École des Hautes Études en Sciences Sociales.

Dubois, H. 1938. Monographie des Betsileo. Paris: Institut d'Ethnologie.

Freeman, L. 2001. "Knowledge, education and social differentiation amongst the Betsileo of Fisakana, Madagascar." PhD diss., University of London.

Harper, J. 2002. Endangered Species: Health, Illness and Death among Madagascar's People of the Forest. Durham: Carolina University Press.

Holder Rich, C., ed. 2008. The Fifohazana: Madagascar's Indigenous Christian Movement. Amherst: Cambria Press.

Jacquier-Dubourdieu, L. 1996. "Représentation de l'esclavage et conversion: un aspect du mouvement du réveil à Madagascar.” Cahiers Sciences Humaines 32(3): 597-610. 
Keller, E. 2005. The Road to Clarity: Seventh-Day Adventism in Madagascar. New York: Palgrave MacMillan.

Kottak, C. 1980. The Past in the Present: History, Ecology and Variation in Highland Madagascar. Ann Arbor: University of Michigan Press.

Kus, S. and V. Raharijaona. 1990. "Domestic space and the tenacity of tradition among some Betsileo of Madagascar". In, Domestic Architecture and the Use of Space: An Interdisciplinary Cross-Cultural Study, edited by S. Kent, 21-33. Cambridge: Cambridge University Press.

Legrip-Randriambelo, O. 2014. "L’intermédicalité malgache. Itinéraires thérapeutiques sinueux en région Betsileo." In Autour du soin. Pratiques, représentations, épistémologie, edited by T. Pierre, A. Fernandes, D. Kessler-Bilthaeur, S. Megherbi and Q. Morales La Mura, 115-128. Nancy: Presses Universitaires de Nancy.

Mestre, C. 2013. Maladies et violences ordinaires dans un hôpital malgache, Paris: L'Harmattan.

Noiret, F. 1995. Chants de lutte, chants de vie à Madagascar: les zafindraony du pays Betsileo. Paris: L'Harmattan.

Rakotomalala, M. 2002. "Transformations du politique et pluralité thérapeutique." Journal des anthropologues 8889. Online publication: http://jda.revues.org/2803.

Rakotomalala, M., S. Blanchy, and F. Raison-Jourde. 2001. Les ancêtres au quotidien. Usages sociaux du religieux sur les Hautes-Terres malgaches. Paris: L'Harmattan.

Sharp L. A. 1993. The Possessed and the Dispossessed: Spirits, Identity, and Power in a Madagascar Migrant Town. Berkeley: University of California Press. 